\title{
Ali lahko izkušnjo kaznovanja v vzgoji iz otroštva povezujemo z depresivnimi ali s tesnobnimi stanji v odraslosti?
}

\author{
SaŠa Poljak Lukek* \\ Teološka fakulteta, Univerza v Ljubljani
}

\begin{abstract}
Povzetek: Kaznovanje, ki ga razumemo kot odziv staršev na neželeno vedenje otroka in pomeni omejevanje takega vedenja, je sestavni del vzgojnega delovanja staršev v družini. Tesnobna in depresivna stanja skozi paradigmo afektivne regulacije predstavljajo ponovni neuspeli poskus približevanja in iskanja stika v odnosu. V raziskavi, v katero je bilo vključenih 197 posameznikov, smo preučevali povezave med kaznovanjem v vzgoji in motnjami razpoloženja v odraslosti. Depresivna stanja v odraslosti se statistično pomembno, vendar šibko pozitivno povezujejo z izkušnjo telesnega kaznovanja, kazni in restitucije ter psihičnega nasilja obeh izmed staršev. Tesnobna stanja se statistično pomembno, vendar šibko pozitivno povezujejo z izkušnjo psihičnega nasilja obeh staršev in z izkušnjo telesnega nasilja ter kazni in restitucije matere. Udeleženci, ki dosegajo kriterije za diagnozo depresije, so bili pri 10 letih starosti statistično pomembno pogosteje telesno kaznovani (od obeh staršev), vzgajani s kaznijo in z restitucijo (od očeta) ter s psihičnim nasiljem (od očeta) kot udeleženci brez diagnoze depresije. Paradigma afektivne regulacije je predstavljena kot možna razlaga povezav med izkušnjami kaznovanja kot vzgojnega sredstva v otroštvu in poznejšimi težavami v razpoloženju odrasle osebe. Kaznovanje v vzgoji, pri čemer starši ne ohranjajo stika z otrokom, je lahko prva izkušnja negativnega afekta, ki je jedro tesnobnih in depresivnih stanj. Motnje razpoloženja v odraslosti pa lahko razumemo kot ponovni neuspeh vzpostavitve ravnotežja med zunanjimi informacijami in notranjim doživljanjem, ki je bilo prvotno porušeno ob izkušnji kaznovalne vzgoje.
\end{abstract}

Ključne besede: vzgojne prakse, kaznovanje, depresivnost, anksioznost, uravnavanje čustev

\section{Can an experience of a punishment episode in childhood period be connected with depressive or anxiety conditions in adulthood?}

\author{
Saša Poljak Lukek \\ Faculty of Theology, University of Ljubljana, Slovenia
}

\begin{abstract}
Punishment, when understood as parents' response to undesirable behavior of a child and representing gradual restricting of such behavior, is an essential part of parents' role in the family. In the context of the paradigm of affective regulation, anxiety and depression states represent another unsuccessful attempt of trying to get closer and to find a connection in the relationship. This study, conducted on 197 participants, addressed the connection between punishment in upbringing and behavior disturbances in adulthood. Depressive states in adulthood were statistically significantly, although weakly connected with the experience of corporal punishment, punishment and restitution, and psychological aggression form both parents. Anxiety states were statistically significantly, although weakly connected with the experience of psychological aggression from both parents and with the experience of corporal punishment, and punishment and restitution of the mother. The participants who attained the criteria for diagnosis of depression were more exposed to corporal punishment at the age of 10 years (from both parents), punishment and restitution (from the father) and psychological aggression (from the father) compared to the participants without the diagnosis of depression. The paradigm of affective regulation is presented as a possible explanation of the connection between experiences of punishment as a way of upbringing in childhood and later mood disorders in adulthood. Punishment during upbringing that is not accompanied by parents' maintaining of the connection with the child can present the first experience of negative affection, which is the core of anxiety and depressive states. The mood disorders in adulthood can be understood as another failure when trying to reestablish the balance between external information and internal experiences that were primarily disturbed by the experience of punishment when growing up.
\end{abstract}

Key words: childrearing practices, punishment, depression, anxiety, emotional regulation

\footnotetext{
${ }^{*}$ Naslov/Address: dr. Saša Poljak Lukek, Teološka fakulteta, Univerza v Ljubljani, Poljanska cesta 6, 1000 Ljubljana, e-mail: sasa.
} poljak@teof.uni-lj.si

Članek je licenciran pod pogoji Creative Commons Attribution 4.0 International licence. (CC-BY licenca).

The article is licensed under a Creative Commons Attribution 4.0 International License (CC-BY license). 


\section{Kaznovanje kot vzgojno sredstvo}

Ko otroka definiramo kot bitje s potenciali, vzgojo razumemo kot težnjo $\mathrm{k}$ razvijanju teh potencialov in spodbujanju $\mathrm{k}$ moralnemu in sprejemljivemu načinu vedenja (Peček Čuk in Lesar, 2009). Cilj vzgoje je tako integracija otrokvdružino in okoljeznadzorom, zahtevami, discipliniranjem in odzivanjem na neželeno vedenje otroka (Anderson in Sabatelli, 2007). Discipliniranje v vzgoji lahko opredelimo kot ciljno usmerjeno vplivanje staršev na otroka z namenom oblikovanja sprejemljivega, prilagojenega vedenja otroka in njegove samokontrole (Salkind, 2002), pri čemer kaznovanje opredeljujemo kot enega izmed načinov discipliniranja otrok v družini (Socolar, Savage in Evans, 2007; Socolar, Savage, KeyesElstein in Evans, 2005; Straus in Fauchier, 2007). Med kaznovalne vzgojne metode štejemo telesno kaznovanje, psihično nasilje, omejevanje privilegijev in restitutivno vedenje (Straus in Fauchier, 2007).

Raziskave so pokazale, da so starši kljub razširjenosti kaznovalnih načinov discipliniranja (Poljak, 2009; Straus in Stewart, 1999) pri odzivanju na otrokovo neželeno vedenje pretežno uporabljali nekaznovalne načine discipliniranja (Kornhauser in Pleterski-Rigler, 2007; Poljak, 2009; Socolar idr., 2005; Straus in Field, 2003). V Sloveniji je več kot polovica staršev poročala o uporabi vsaj ene oblike telesnega kaznovanja oziroma vsaj ene oblike psihičnega nasilja kot načina discipliniranja otrok v družini; tretjina staršev je svojega otroka v zadnjem letu našeškala, udarila oziroma klofnila, šestina staršev je za telesno kaznovanje že uporabila kuhalnico, krtačo, pas ali drug predmet (Poljak, 2009).

Številni raziskovalci so iskali povezave med kaznovalnimi vzgojnimi metodami in razvojem problematičnega vedenja (Aucoin, Frick in Bodin, 2006; Gershoff, 2002; Grogan-Kaylor, 2004; Lynch idr., 2006; Mulvaney in Mebert, 2007; Straus, 1994; Straus in Mouradian, 1998; Straus, Sugarman in Giles-Sims, 1997) ter problematičnega čustvovanja pri otroku (Aucoin idr., 2006; MacMillan idr., 1999). Izkazalo se je, da so imeli otroci, ki so bili redno fizično kaznovani, več vedenjskih težav kot otroci brez izkušnje fizičnega kaznovanja (Aucoin idr., 2006). Kaznovanje v vzgoji se je povezovalo $\mathrm{z}$ antisocialnim vedenjem (Grogan-Kaylor, 2004; Straus in Mouradian, 1998; Straus idr., 1997), impulzivnim vedenjem (Aucoin idr., 2006; Straus in Mouradian, 1998) ter tudi $\mathrm{z}$ depresivnimi in $\mathrm{s}$ tesnobnimi motnjami (MacMillan idr., 1999). Nekateri avtorji pa so opozarjali, da se večina povezav nanaša na nasilno fizično kaznovanje v družini, medtem ko so bili dokazi za povezavo med drugimi oblikami kaznovanja in poznejšim razvojem vedenjskih in čustvenih težav šibki (Baumrind, Larzelere in Cowan, 2002; Larzelere, 2000; Lynch idr., 2006; Oddone Paolucci in Violato, 2004; Trumbull, Larzelere, Wolraich in Trumbull, 1999). Raziskava, ki je izključila posameznike $\mathrm{z}$ izkušnjo zlorabe $\mathrm{v}$ otroštvu, je pokazala na statistično pomembne razlike med posamezniki, ki so bili v otroštvu telesno kaznovani, in tistimi, ki niso bili. Posamezniki z izkušnjo telesnega kaznovanja $\mathrm{v}$ otroštvu so doživljali več tesnobe, pogosteje so postali odvisni od alkohola in imeli več vedenjskih težav (MacMillan idr., 1999). Psihični mehanizmi, ki naj bi se oblikovali pri izkušnji kaznovalne vzgoje in se povezujejo s poznejšimi vedenjskimi in čustvenimi težavami, pa ostajajo precej nepojasnjeni. F. W. K. Harper in I. Arias (2004) v svojem delu predlagata, da naj bi bil občutek sramu dejavnik, ki oblikuje povezavo med kaznovanjem $v$ vzgoji in jezo pri moških ter povezavo med kaznovanjem in depresijo pri ženskah. Kazen v vzgoji poleg telesnega kaznovanja vključuje tudi psihično nasilje, omejevanje in restitutivno vedenje (Straus in Fauchier, 2007), za katere pa še ni zadostnih dokazov o njihovem odnosu s poznejšimi vedenjskimi in čustvenimi težavami.

\section{Tesnobna in depresivna stanja skozi paradigmo afektivne regulacije}

Tesnobno stanje je neprijeten telesni občutek in psihična napetost, ki ni (tako kot pri strahu) usmerjena na trenutno situacijo in neposredne okoliščine, ampak v pričakovane negativne posledice $\mathrm{v}$ prihodnosti (Barlow in Durand, 2005). Doživljanje tesnobe v odnosih lahko povzroči, da oseba drugega ne more videti kot nekoga, h kateremu lahko gre po pomoč ali oporo, ampak kot nekoga, ki je nevaren in vir vseh negativnih afektov, ki jih telo ne more pomiriti (Gostečnik, 2007). Negativni afekt oziroma psihična vznemirjenost, ki jo poznamo pri tesnobnih stanjih, je značilna tudi za depresivna stanja. Medtem ko je za tesnobno stanje značilna telesna vznemirjenost,depresivno razpoloženje spremlja odsotnost pozitivnega afekta (Brown, Chorpita in Barlow, 1998). V odnosih se depresivna stanja kažejo kot odsotnost empatije (Gostečnik, 2007) oziroma kot zanikanje čustvenih reakcij, ki jih posameznik doživlja kot ogrožajoča, saj meni, da jih bodo osebe ob izražanju čustev zapustile (Miller, 1979).

Depresivna in tesnobna stanja se odražajo $\mathrm{z}$ vedenjem. Carver in Scheier (2003) v kontekstu paradigme afektivne regulacije izhajata iz predpostavke, da vedenje usmerja težnja po izogibanju oziroma težja po približevanju določenemu cilju. Če so vzgojni ukrepi za otroka nerazumljiv razkorak med notranjim doživljanjem in zunanjimi informacijami, otrok svoje vedenje prilagaja $\mathrm{v}$ smeri zmanjševanja teh razlik. Carver in Scheier (2003) menita, da depresivno stanje povzroča občutek neuspeha pri zmanjševanju različnosti med zunanjimi informacijami in notranjim doživljanjem ter da tesnobno stanje povzroči neuspeh pri izogibanju razkoraku med notranjim doživljanjem in zunanjimi informacijami. $\mathrm{Z}$ vidika relacijske družinske paradigme (Gostečnik, 2004) so depresivna stanja nedosežena želja po odnosu, v katerem se oseba čuti brezpogojno sprejeta, ljubljena in zaželena. Tesnobno stanje pa lahko z vidika relacijske paradigme (Gostečnik, 2004) razložimo s poskusom izogibanja že poznani psihični bolečini. Oseba, ki v otroštvu ni bila slišana $\mathrm{v}$ svojih potrebah in čustvih, se pred vnovično bolečino zavaruje $\mathrm{z}$ izogibanjem soočenja s čustvenimi odzivi. 


\section{Kaznovanje kot vzgojno sredstvo ter tesnobna in depresivna stanja $v$ odraslosti}

Kaznovanje v vzgoji naj bi preprečevalo neželeno vedenje otroka. Ta naj bi svoje vedenje prilagodil okolici glede na pričakovane posledice kazni. Ko otrok razume povezavo med kaznijo in lastnim vedenjem, lahko vedenje oblikuje tako, da se kazni izogne (Peček Čuk in Lesar, 2009). Tako lahko odnos med izkušnjo kaznovanja v vzgoji in vedenjem (tudi v odraslosti) pojasnimo z oblikovanjem vzorcev izogibajočih in kontrolirajočih vedenjskih vzorcev (Carver in Scheier, 2003). Ti so funkcionalni, če vzgajani uspe povezati kazen s svojim vedenjem, in lahko postanejo nefunkcionalni, če kaznovanje predstavlja nevarnost, ki se ji ne more izogniti. V kontekstu prisotnosti kaznovanja v otroštvu lahko depresivna stanja v odraslosti razumemo kot izraz vnovičnega neuspeha pri vzpostavljanju odnosov, ki jih je kaznovanje prekinilo, in tesnobna stanja kot izraz vnovičnega neuspeha pri izogibanju bolečini, ki jo je povzročilo kaznovanje v vzgoji.

Chorpita in Barlow (1998) pojasnjujeta, da je izvor razvoja nagnjenosti $\mathrm{k}$ tesnobnemu razpoloženju $\mathrm{v}$ zgodnjem odnosu med starši in otrokom, v katerem se otrok uči kontrolirati vedenje, čustvovanje in mišljenje. Otroka starši, ki se na njegove potrebe odzivajo pozitivno in konsistentno, učijo, kako lahko kontrolira svoje doživljanje in okolico ter kako njegovo vedenje vpliva na okolico (Chorpita in Barlow, 1998). Negativno, pretirano in grobo kaznovalno odzivanje na otrokove potrebe tako lahko povzroči nezmožnost obvladovanja notranjega doživljanja in zunanjih dražljajev, kar lahko povzroči tesnobna stanja. Ob intenzivnem in dlje trajajočem izpostavljanju nasilnim kaznovalnim vzgojnim ukrepom lahko tesnobno doživljanje razumemo kot odziv na nekoč doživete nevarnosti (Rothschild, 2000). Oseba v odraslem odnosu lahko ob dražljaju, ki spominja na pretekle zlorabe, podoživi strah in jezo, ki se lahko razvije $\mathrm{v}$ skrajne oblike tesnobnega doživljanja, kot je na primer panični napad. Oseba si v tem primeru čustev ne more razložiti oziroma jih nadzirati, saj na videz niso povezana s trenutno situacijo, kar le še povečuje občutek nemoči, krivde in strahu. Hindy in Schwarz (1994) sta $\mathrm{z}$ raziskavo odnosov pri odraslih ugotovila, da so posamezniki $\mathrm{z}$ večjo tendenco $\mathrm{k}$ tesnobnemu doživljanju v odnosih svoje starše pogosteje opisovali kot neredne pri izražanju naklonjenosti in ljubezni ali kot zelo posesivne v odnosu do njih. Nepredvidljiva in posesivna vzgoja pomeni neprestano nevarnost zaradi nepredvidljivih posledic in nepredvidljivega kaznovanja, stalni neuspeh pri izogibanju pričakovani nevarnosti pa oblikuje afekt tesnobnega stanja v odraslosti (Carver in Scheier, 2003).

Za razlago depresivnih stanj kot posledice neuspelega približevanja želenemu cilju moramo iskati drugačne razlage. Depresivna stanja so v primerjavi s tesnobnimi v manjši meri povezana z izgubljenim občutkom kontrole in $\mathrm{v}$ večji meri z občutkom manjvrednosti ter s podrejenim, pokornim vedenjem. Stuewig in L. McCloskey (2005) sta $\mathrm{z}$ longitudinalno raziskavo preučevala povezavo med doživljanjem sramu in krivde v otroštvu in depresivnimi simptomi v odraslosti. Ugotovila sta, da je bilo doživljanje sramu povezano $\mathrm{s}$ kritiziranjem, $\mathrm{z}$ odklanjanjem in $\mathrm{s}$ sramotenjem na strani staršev v obdobju mladostništva in da je bilo doživljanje krivde povezano z oddaljenim odnosom med starši in otrokom v obdobju mladostništva. A. Miller (1979) tako vedenje staršev opisuje kot izraz njihove nemoči razumeti otrokove potrebe in se na njih ustrezno odzvati, s čimer v odnosu z otrokom prevladuje skrb za starševske, in ne otrokove potrebe. Pri tem poudarja, da osebe, ki iščejo strokovno pomoč zaradi neobvladljivih depresivnih stanj, pogosto opisujejo nemoč, nekonsistentnost in neodločnost svojih staršev. Starši, ki kažejo nemoč tudi s kaznovalnimi vzgojnimi ukrepi, v otroku vzbudijo strah za lasten obstoj, ki se lahko odraža tudi v depresivni simptomatiki v odraslosti. Po paradigmi afektivne regulacije lahko depresivno stanje povzroči ponovni neuspeli poskus približevanja želenemu cilju (ohranjanje odnosa) oziroma zmanjševanja različnosti med zunanjimi informacijami in notranjim doživljanjem (Carver in Scheier, 2003).

Kaznovanje v vzgoji naj bi oblikovalo pogoje za doživljanje depresivnih in tesnobnih stanj $\mathrm{v}$ odraslosti, pri čemer še vedno nimamo dokončnega odgovora na vprašanje, kateri psihološki mehanizmi se oblikujejo z izkušnjo kaznovalne vzgoje, ki to povezavo omogočajo. Dozdajšnje raziskave so pokazale, da telesno kaznovanje lahko povezujemo s poznejšimi razpoloženjskimi motnjami v odraslosti (MacMillan idr., 1999; Stuewig in McCloskey, 2005). Če naj bi vzgoja zajemala tudi kaznovanje (Anderson in Sabatelli, 2007; Maccoby in Martin, 1983; Peček Čuk in Lesar, 2009), se zastavlja vprašanje, kateri načini kaznovanja $\mathrm{v}$ vzgoji lahko prispevajo $\mathrm{k}$ razvoju avtonomne osebnosti in ohranjajo funkcionalnost $\mathrm{v}$ odnosih ter kako lahko kaznovanje $\mathrm{v}$ vzgoji povezujemo s poznejšimi težavami v odraslosti. Pričujoča raziskava želi odgovoriti na vprašanje, ali se metode kaznovanja v vzgoji med seboj razlikujejo glede na povezave $\mathrm{z}$ depresivnimi in $\mathrm{s}$ tesnobnimi stanji $\mathrm{v}$ odraslosti in kateri načini omejevanja vedenja v vzgoji vodijo $\mathrm{v}$ oblikovanje funkcionalnih načinov vedenja in čustvovanja ter za katere lahko predvidevamo, da prispevajo $\mathrm{k}$ težavam $\mathrm{v}$ čustvenem doživljanju odrasle osebe.

\section{Metoda}

\section{Udeleženci}

Vprašalnik je izpolnilo 197 študentov dveh fakultet Univerze v Ljubljani, od tega 29 moških (14,7 \%) in 168 žensk $(85,3 \%)$. Povprečna starost udeležencev je bila 21,3 leta $(S D=4,21)$. Med vprašanimi je bilo $96(48,7 \%)$ samskih, 68 (34,5\%) jih je bilo v odnosu, vendar niso živeli s partnerjem, 22 (11,2 \%) jih je živelo s partnerjem, $2(1 \%)$ sta bila poročena in $8(4,1 \%)$ jih svojega statusa ni opredelilo. Pri 131 (66,5 \%) udeležencih so bili starši poročeni in so živeli skupaj, pri $34(17,3 \%)$ so bili ločeni, pri $19(9,6 \%)$ je bil vsaj eden od staršev pokojni, pri 8 (4,1 \%) so biološki starši živeli skupaj, a niso bili poročeni, pri 
4 (2\%) pa starši nikoli niso živeli skupaj. Odhod enega od staršev zaradi ločitve ali smrti se je za $28(14,2 \%)$ udeležencev zgodil pred 10. letim starosti, za 22 (11,2 \%) po 10 . letu starosti in za $3(1,5 \%)$ pri 10 . letih starosti.

\section{Pripomočki}

$\mathrm{V}$ raziskavi je uporabljen zbirnik vprašalnikov mednarodne raziskave o starševstvu (Straus, 2010a). V raziskavo je do zdaj vključenih več držav, in sicer dve afriški, štiri azijske, ena država Oceanije, deset evropskih držav (leta 2009 se je pridružila tudi Slovenija), dve latinskoameriški, ena srednjevzhodna, dve državi Severne Amerike in Združene države Amerike, ki so nosilke raziskave (Straus, 2010b). Besedilo izvirnika so za raziskavo v Sloveniji prevedli trije neodvisni prevajalci, nato pa je bila usklajena različica znova prevedena $\mathrm{v}$ angleščino. Angleška različica je bila poslana avtorjem izvirnika, njihove pripombe pa so bile upoštevane pri oblikovanju končne različice vprašalnika, ki je bila uporabljena v raziskavi.

DDI - vprašalnik o dimenzijah discipliniranja (Straus in Fauchier, 2007). Šestindvajset trditev vprašalnika se nanaša na dva načina discipliniranja, in sicer nekaznovalnega in kaznovalnega. Lestvica kaznovalnega discipliniranja vključuje štiri podlestvice za različne načine kaznovalnega discipliniranja: telesno kazen (štiri postavke), omejevanje privilegijev (štiri postavke), kazen in restitucijo (tri postavke) ter psihično nasilje (štiri postavke) (Straus in Fauchier, 2007). Odgovorni format postavk predstavlja večstopenjska lestvica, s katerimi ugotavljamo pogostost uporabe posameznega kaznovalnega načina discipliniranja otrok $\mathrm{v}$ družini $\mathrm{v}$ zadnjem letu. Uporabljena je devet-stopenjska lestvica, pri čemer prva stopnja pomeni nikoli uporabljen kaznovalni način discipliniranja, deveta pa, da je kaznovalni način uporabljan vsaj dvakrat dnevno. Za nadaljnjo analizo smo podatke iz večstopenjskih lestvic prevedli $\mathrm{v}$ frekvence pogostosti uporabe posameznega načina discipliniranja $\mathrm{v}$ zadnjem letu. Zanesljivost vprašalnika dimenzij discipliniranja so avtorji ugotavljali s pilotsko raziskavo med 498 študenti, pri čemer je Cronbachov alfa koeficient za kaznovalno discipliniranje matere znašal 0,89 , za kaznovalno discipliniranje očeta pa 0,88 . Cronbachov alfa koeficient v predstavljeni raziskavi je za kaznovalno discipliniranje matere znašal 0,88 , za kaznovalno discipliniranje očeta pa 0,84 .

MDI - vprašalnik o depresiji (Olsen, Jensen, Noerholm, Martiny in Bech, 2003). Zajema dvanajst trditev, s katerimi merimo intenzivnost depresivnega stanja (blaga depresija, zmerna depresija, resna depresija). Odgovorni format postavk predstavlja Linkertova pet-stopenjska lestvica. Kriterijska veljavnost je bila preverjena na podlagi Hamiltonove lestvice depresivnosti (HAM-D; Olsen idr., 2003). Ugotovili so, da je korelacija med lestvicama visoko pozitivna $(r=0,86$; Olsen idr., 2003). Interna konsistentnost lestvice, ocenjena v okviru mednarodne raziskave o starševstvu, je bila zadovoljiva $(\alpha=0,89)$.
Kontrolni seznam simptomov (CLS-90) s tremi trditvami ocenjuje tesnobna doživljanja posameznika (Olsen, Mortensen in Bech, 2004). Odgovorni format postavk predstavlja pet-stopenjska lestvica. Vrednost Loevingerjevega koeficienta $(0,50)$ kaže na zadostno zanesljivost tesnobne lestvice (Olsen idr., 2004). Cronbachovalfa koeficient, ocenjen v okvirumednarodne raziskave o starševstvu, je za kontrolni seznam simptomov znašal 0,79.

\section{Postopek}

Vprašalniki mednarodne raziskave o starševstvu so bili razdeljeni med študente in študentke dveh fakultet Univerze $\mathrm{v}$ Ljubljani. $\mathrm{Z}$ informiranim soglasjem so jim bile podane vse informacije o raziskavi, potem so bili povabljeni k sodelovanju. Študentje v Sloveniji za udeležbo pri raziskavi niso prejeli nikakršnega plačila oziroma dodatnih kreditnih točk, ki bi jih lahko uveljavljali pri svojih študijskih obveznostih. Sodelovanje je bilo prostovoljno, izvajalci raziskave so zagotovili anonimnost. Udeleženci so bili pozvani, naj ne podpisujejo vprašalnika, in se pred izpolnjevanjem niso identificirali. Študentje, ki so se odločili za sodelovanje, so izpolnjene vprašalnike oddali v škatlo. Če se za sodelovanje niso odločili, so oddali prazen vprašalnik $\mathrm{v}$ isto škatlo, pri čemer ni bilo mogoče ugotoviti, kateri izmed študentov vprašalnika ni izpolnil.

Za raziskavo je bilo, kot nalaga protokol, pridobljeno soglasje etične komisije. Za pristop $\mathrm{k}$ raziskavi je bilo pridobljeno soglasje matične fakultete koordinatorice raziskave za Slovenijo. V nadaljevanju raziskovanja pa je protokol izvedbe raziskave odobrila tudi Komisija Republike Slovenije za medicinsko etiko.

Zaradi potencialnega tveganja raziskave, ki se navezuje naizpolnjevanje vprašanj, povezanih zobčutljivimitemami o družinskih odnosih, z agresijo med družinskimi člani, s preteklostjo kriminalnega vedenja in psihološko stisko, so vsi udeleženci ob koncu izpolnjevanja vprašalnika prejeli dokument $\mathrm{z}$ informacijami o raziskavi in ustreznimi kontaktnimi podatki za pomoč $\mathrm{v}$ stiski. Vprašanja o nezakonitem vedenju ne vključujejo kaznivih dejanj, ki jih je treba zakonsko prijaviti po uradni dolžnosti.

\section{Rezultati}

\section{Razširjenost kaznovalnih načinov vzgoje}

Opisne statistike, predstavljene v tabeli 1, se nanašajo na razširjenost posameznih kaznovalnih načinov vzgoje otrok v družini. Več kot $90 \%$ mater in očetov je vsaj enkrat uporabilo kaznovalni način discipliniranja. Več kot polovica jih je uporabila telesno kaznovanje in kar $92,4 \%$ mater in $88,3 \%$ očetov psihično nasilje.

Poleg podatkov predstavljenih v tabeli 1 , smo dodatno ugotovili, da so matere udeležencev raziskave (v povprečju) v $39 \%$ uporabljale kaznovalne načine discipliniranja in v $61 \%$ nekaznovalne načine. Večina (58 \%) očetov naj bi pri vzgoji uporabljala nekaznovalne načine, $42 \%$ očetov 
Tabela 1: Odstotek staršev, ki so pri udeleženčevih desetih letih uporabljali posamezni kaznovalni način discipliniranja $(N=197)$

\begin{tabular}{|c|c|c|}
\hline način discipliniranja & $\begin{array}{l}\text { razširjenost- } \\
\text { mati }(\%)\end{array}$ & $\begin{array}{c}\text { razširjenost } \\
- \text { oče }(\%)\end{array}$ \\
\hline KAZNOVALNO DISCIPLINIRANJE & 96,6 & 92,5 \\
\hline TELESNA KAZEN & $\mathbf{5 8 , 9}$ & 56,1 \\
\hline stresti oziroma trdo prijeti otroka, da bi pridobili njegovo/njeno pozornost & 44,4 & 44,4 \\
\hline našeškati, udariti oziroma klofniti otroka & 51,3 & 45,0 \\
\hline uporabiti kuhalnico, krtačo, pas oziroma drugi predmet & 25,5 & 20,2 \\
\hline $\begin{array}{l}\text { umiti otrokova usta z milom, dali začimbo na njegov jezik ali naredili kaj podob- } \\
\text { nega }\end{array}$ & 1,5 & 2,1 \\
\hline OMEJEVANJE PRIVILEGIJEV & 68,4 & 63,8 \\
\hline odvzeti žepnino, igračo ali druge privilegije zaradi neprimernega vedenja & 43,1 & 37,4 \\
\hline poslati otroka $\mathrm{v}$ posteljo brez obroka & 7,1 & 5,3 \\
\hline odvzeti žepnino, igračo ali drugi privilegij, dokler otrok ne naredi, kar se zahteva & 38,7 & 36,6 \\
\hline $\begin{array}{l}\text { zadržati otroka doma oziroma mu omejili aktivnosti zunaj doma zaradi njegovega } \\
\text { neprimernega vedenja }\end{array}$ & 57,9 & 48,4 \\
\hline KAZEN IN RESTITUCIJA & 87,1 & 81,1 \\
\hline naložiti otroku dodatna opravila kot posledico neprimernega vedenja & 68,9 & 63,3 \\
\hline od otroka zahtevati, da se oddolži za svoje neprimerno vedenje & 44,1 & 39,6 \\
\hline prisiliti otroka, da se opraviči oziroma reče, da mu je žal za neprimerno vedenje & 70,3 & 64,9 \\
\hline PSIHIČNO NASILJE & 92,4 & 88,3 \\
\hline kričati oziroma vpiti na otroka & 82,9 & 73,7 \\
\hline otroku skušati zbuditi občutek sramu oziroma krivde & 56,1 & 53,2 \\
\hline $\begin{array}{l}\text { zadrževati naklonjenost oziroma se vesti hladno pred otrokom ter ga ne objeti } \\
\text { oziroma poljubiti }\end{array}$ & $\begin{array}{l}43,2 \\
746\end{array}$ & $\begin{array}{l}45,2 \\
697\end{array}$ \\
\hline
\end{tabular}

pa kaznovalne. Med kaznovalnimi načini discipliniranja je najpogostejši način kaznovanja pri materah in očetih psihično nasilje, ki pri materah zajema $21 \%$ vseh vzgojnih ukrepov in pri očetih $24 \%$.

\section{Povezave med kaznovalnimi načini vzgoje in poznejšimi prilagoditvami $v$ odraslosti}

$\mathrm{V}$ tabeli 2 smo za izračun mere povezanosti med ordinalno (oceno prilagoditev v odraslosti, ki se kažejo kot ali depresivna ali tesnobna stanja) in razmernostno spremenljivko (pogostost uporabe načinov discipliniranja) uporabili Spearmanov korelacijski količnik. Depresivna stanja v odraslosti se statistično pomembno, vendar šibko pozitivno povezujejo s pogostostjo telesnega kaznovanja, $\mathrm{s}$ kaznijo in $\mathrm{z}$ restitucijo ter s psihičnim nasiljem obeh staršev. Tesnobna stanja se statistično pomembno, vendar šibko pozitivno povezujejo $\mathrm{s}$ pogostostjo psihičnega nasilja obeh staršev ter s pogostostjo telesnega nasilja ter kazni in restitucije matere.

S Kolmogorov-Smirnov testom smo ugotovili, da na 5-odstotni ravni tveganja porazdelitve dosežkov na vseh lestvicah kaznovalnega discipliniranja statistično pomembno odstopajo od normalne porazdelitve. Za testiranje hipotez o različnosti mer centralne tendence med neodvisnimi vzorci smo uporabili neparametrični Mann-Whitneyjev test. Glede na stopnjo depresivnosti obstajajo statistično pomembne razlike $(U=-2,036, p$ $=0,042)$ med skupino udeležencev raziskave, katerih očetje so se odločali za telesno kazen $(N=128$, povprečje rangov $=100,02$, vsota rangov $=12803)$, in skupino tistih, katerih očetje telesnega kaznovanja niso izvajali $(N=60$, povprečje rangov $=82,72$, vsota rangov $=4963)$. Udeleženci raziskave, katerih očetje so se odločali za telesno kazen, torej dosegajo statistično pomembno višjo stopnjo depresivnosti v odraslosti od oseb, ki o očetovem

Tabela 2. Korelacijski koeficienti (Spearmanov $\rho$ ) med načini discipliniranja matere ter očeta in prilagoditvami $v$ odraslosti $(N=197)$

\begin{tabular}{|c|c|c|c|c|c|c|c|c|c|c|}
\hline & \multicolumn{2}{|c|}{$\begin{array}{l}\text { KAZNOVALNO } \\
\text { DISCIPLINIRANJE }\end{array}$} & \multicolumn{2}{|c|}{$\begin{array}{l}\text { Telesno } \\
\text { kaznovanje }\end{array}$} & \multicolumn{2}{|c|}{$\begin{array}{l}\text { Omejevanje } \\
\text { privilegijev }\end{array}$} & \multicolumn{2}{|c|}{$\begin{array}{l}\text { Kazen in } \\
\text { restitucija }\end{array}$} & \multicolumn{2}{|c|}{ Psihično nasilje } \\
\hline & mati & oče & mati & oče & mati & oče & mati & oče & mati & oče \\
\hline Depresivna stanja & $0,20^{* *}$ & $0,32^{* *}$ & $0,17^{*}$ & $0,26^{* *}$ & 0,06 & 0,11 & $0,19^{*}$ & $0,19^{*}$ & $0,17^{*}$ & $0,33^{* *}$ \\
\hline Tesnobna stanja & $0,20^{* *}$ & $0,28^{* *}$ & $0,18^{*}$ & 0,12 & 0,06 & 0,05 & $0,15^{*}$ & 0,09 & $0,18^{*}$ & $0,22^{* *}$ \\
\hline
\end{tabular}

${ }^{*} p<0,05 ;{ }^{* *} p<0,01$ 
Tabela 4. Statistike Mann-Witheyevega testa za primerjavo med skupino brez simptomov depresije in skupino $s$ simptomi depresije glede na način kaznovanja matere $v$ vzgoji

\begin{tabular}{lccrr}
\hline & Brez simptomov & S simptomi depresije & & \\
\cline { 2 - 4 } & $M_{\text {rang }}$ & $M_{\text {rang }}$ & $-2,346$ & 0,019 \\
\hline Telesna kazen & 92,95 & 117,38 &,- 044 & 0,965 \\
Omejevanje privilegijev & 96,58 & 96,11 & $-1,780$ & 0,075 \\
Kazen in restitucija & 93,82 & 113,13 & $-1,947$ & 0,052 \\
Psihično nasilje & 93,51 & 114,55 & \\
\hline
\end{tabular}

Tabela 5. Statistike Mann-Witheyevega testa za primerjavo med skupino brez simptomov depresije in skupino s simptomi depresije glede na način kaznovanja očeta v vzgoji

\begin{tabular}{lcccc}
\hline & \multicolumn{1}{c}{ Brez simptomov } & S simptomi depresije & & \\
\cline { 2 - 5 } & $M_{\text {rang }}$ & $M_{\text {rang }}$ & $-2,865$ & 0,004 \\
\hline Telesna kazen & 88,67 & 117,65 & $-1,186$ & 0,236 \\
Omejevanje privilegijev & 90,96 & 103,13 & $-1,979$ & 0,048 \\
Kazen in restitucija & 90,46 & 111,16 & $-3,606$ & 0,000 \\
Psihično nasilje & 87,02 & 124,64 & \\
\hline
\end{tabular}

telesnem kaznovanju ne poročajo. Za preostale kaznovalne načine vzgoje ničelne hipoteze o razlikah med skupinami ne moremo ovreči.

Pri nadaljnjem testiranju hipotez različnosti skupin glede na pogostost kaznovanja smo z Mann-Witneyjevim testom preverjali razlike med skupinama udeležencev brez simptomov za diagnozo depresije $(N=162)$ in udeležencev s simptomi depresije ( $N=32$; tabeli 3 in 4). Udeleženci, ki dosegajo kriterije za diagnozo depresije, so bili pri 10 letih starosti statistično pomembno pogosteje telesno kaznovani (od obeh staršev) ter vzgajani s kaznijo in z restitucijo (od očeta) ter s psihičnim nasiljem (od očeta) kot udeleženci, ki ne dosegajo kriterijev za diagnozo depresije.

\section{Razprava}

Podatki o pogostosti kaznovalnih ukrepov kažejo na dejstvo, da kaznovanje predstavlja pomemben del vzgoje otrok v družini, saj večina udeležencev poroča o njihovi uporabi. Rezultati raziskave potrjujejo povezave med depresivnim in tesnobnim doživljanjem posameznika $\mathrm{v}$ odraslosti in izkušnjami kaznovalnega discipliniranja $\mathrm{v}$ otroštvu. Izkušnja s pretirano omejevalnim vedenjem staršev lahko vpliva na sposobnost nadzora v odraslosti oziroma onemogoča učinkovito kontroliranje lastnega doživljanja (Chorpita in Barlow, 1998) in s tem onemogoča funkcionalne prilagoditve odrasle osebe. Depresivna stanja, ki se kažejo kot obup, negativna razpoloženost, utrujenost, nezanimanje, odsotnost odnosov, otopelost (Brown idr., 1998), so statistično pomembno povezana s telesnim kaznovanjem in psihičnim nasiljem kot vzgojim sredstvom tako matere kot očeta. Korelacijski koeficienti za omenjeni spremenljivki so pozitivni, a nizki in višji pri kaznovalnih vzgojnih metodah očeta. Tudi MannWhitneyjev test kaže na statistično pomembne razlike med udeleženci glede na prisotnost telesnega kaznovanja očeta. Večjo povezanost očetovih kaznovalnih vzgojnih metod $\mathrm{z}$ depresivnimi simptomi $\mathrm{v}$ odraslosti bi lahko pripisali dejstvu, da so lahko depresivna stanja del izogibajočega se vedenja odraslega oziroma izraz pretirane odgovornosti in dolžnosti, ki jo posameznik čuti glede na pretekle izkušnje (Carver in Scheier, 2003), in da velik del občutka odgovornega delovanja posameznik razvije $\mathrm{v}$ odnosu $\mathrm{z}$ očetom (Gostečnik, 2009). Ko izkušnje kaznovanja iz preteklosti nalagajo posamezniku občutek odgovornosti, ki ga ni sposoben dosegati, razvije izogibajoče se vedenje s ciljem izognitve vsakršnemu afektu. Izogibanje povečuje občutek nemoči in oblikuje občutek izgubljene kontrole (Caprara, Regalia in Bandura, 2002; Caprara idr., 1998; Futa, Nash, Hansen in Garbin, 2003), kar lahko povzroča depresivne simptome. Rezultati Mann-Whitneyjevega testa kažejo, da udeleženci brez simptomov za diagnozo depresije poročajo o manjši pogostosti kaznovanja $\mathrm{v}$ vzgoji kot udeleženci s simptomi depresije. Kaznovalni vzgojni ukrepi, pri katerih starši ne ohranjajo stika z otrokom oziroma pri katerih se ne odzivajo na njihove potrebe, so lahko prva izkušnja negativnega afekta, ki se kaže kot razkorak med notranjim doživljanjem in zunanjimi informacijami (Carver in Scheier, 2003), ki ga otrok in pozneje odrasli skuša omiliti. Negativni afekt, ki se pri odraslem odraža $\mathrm{v}$ psihični vznemirjenosti, ki je ne uspe umiriti, je jedro depresivnih simptomov (Brown idr., 1998).

Podobne povezave ugotavljamo tudi za tesnobna stanja, ki se statistično pomembno (a šibko) povezujejo $\mathrm{s}$ telesnim kaznovanjem matere in tudi psihičnim nasiljem matere in očeta. Povečan občutek tesnobe lahko glede na izsledke predhodnih raziskav povezujemo z zmanjšanim občutkom kontrole (Chorpita in Barlow, 1998). Kaznovalni načini vzgoje oziroma predvsem telesna kazen in psihično nasilje staršev omejujeta sposobnost samokontrole. Če telesno kazen in psihično nasilje opredelimo kot načina negativnega odzivanja na otrokove potrebe, lahko ta onemogoča razvoj občutka kontrole, če otroku ob takem kaznovanju ne uspe povezati posledic s svojim vedenjem in nima občutka, da lahko kontrolira te posledice. Omejevanje privilegijev kot način kaznovalnega 
discipliniranja se ne povezuje $\mathrm{z}$ depresivnimi oziroma $\mathrm{s}$ tesnobnimi stanji $\mathrm{v}$ odraslosti. Kazen in restitucija pa se le blago povezujeta $\mathrm{s}$ poznejšimi prilagoditvami $\mathrm{v}$ odraslosti. Obstaja torej možnost, da se telesna kazen in psihično nasilje kot kaznovalno discipliniranje odražata $\mathrm{v}$ prilagoditvah otroka drugače kot omejevanje privilegijev in kazen oziroma restitucija. S stališča samozaznavanja bi lahko rekli, da predvsem omejevanje privilegijev kot kaznovalna vzgojna metoda ne vpliva tako odločilno na občutek kontrole oziroma da je otrok ob takem načinu kaznovanja sposoben oblikovati občutek nadzora, kar pomeni, da je sposoben tudi $\mathrm{v}$ odraslosti ohranjati občutek kontrole nad svojimi zaznavami in odzivi ter da s tem zmanjšuje možnost za depresivna oziroma tesnobna stanja. Tudi B. Rothschild (2000) meni, da je tesnobno doživljanje v sedanjosti lahko posledica odziva na nekoč doživeto nevarnost oziroma izpostavljanja dlje trajajočim kaznovalnim vzgojim ukrepom.

Raziskava nudi izhodišča za razumevanje povezav med kaznovanjem $\mathrm{v}$ vzgoji in poznejšimi motnjami razpoloženja odrasle osebe. Glede na dejstvo, da so korelacije kljub statistični pomembnosti nizke in da so primerjave med skupinami s precej različnim številom, bi bilo za posploševanje rezultatov potrebno še dodatno raziskovanje. Težav v prilagoditvah odrasle osebe seveda ne moremo pripisati zgolj načinu vzgoje. Integrativni pristop $\mathrm{k}$ psihopatologiji vzroke motenj razpoloženja pripisuje odnosu med biološkimi danostmi in stresnimi dogodki $\mathrm{v}$ odnosih (Barlow in Durand, 2005). Tudi na podlagi predstavljenih rezultatov kaznovanje $\mathrm{V}$ vzgoji lahko opišemo kot stresni dogodek v odnosu, ki ob zadostnih bioloških danostih prispeva $\mathrm{k}$ razvoju depresivnih oziroma tesnobnih simptomov. Predvsem telesno kaznovanje in psihično nasilje prepoznavamo kot vzgojna načina, za katera lahko predvidevamo, da prispevata $\mathrm{k}$ težavam $\mathrm{v}$ čustvenem doživljanju odrasle osebe.

Pri navajanju zaključkov raziskave moramo upoštevati njene omejitve. Posploševanje rezultatov na celotno populacijo omejuje dejstvo, da je bilo v raziskavo vključenih več žensk kot moških, torej vzorec po spolu ni uravnotežen. V nekaterih skupinah, kot je bilože omenjeno, pa je bilo malo udeležencev. Prav tako se vprašanja o načinih discipliniranja nanašajo na retrospektivno poročanje na podlagi spomina udeleženca iz otroštva, kar lahko pomeni nevarnost glede popačenosti podatkov. Depresivne osebe lahko zaradi pristranskosti spominskega priklica svoje otroštvo doživljajo bolj negativno. Pri tem je treba poudariti, da rezultati o načinih discipliniranja, pri katerih to spremenljivko ocenjujejo otroci, kažejo podobno razširjenost kot raziskava, v kateri so enako spremenljivko ocenjevali starši (Poljak, 2009). Raziskava kljub omejitvam prispeva $\mathrm{k}$ razumevanju povezav med vzgojo in prilagoditvami $\mathrm{v}$ odraslosti ter odpira nova raziskovalna vprašanja. S preverjanjem učinkovitosti psihoterapevtskega dela $\mathrm{z}$ motnjami razpoloženja lahko ugotavljamo,ali naslovitev izkušenj iz vzgoje pozitivno vpliva na izid terapije oziroma na omilitev motenj. Zastavlja pa se tudi vprašanje, ali lahko s spreminjanjem vzorcev vzgoje $v$ družinah vplivamo na zmanjševanje depresivnih in tesnobnih stanj $\mathrm{v}$ odraslosti.

\section{Literatura}

Anderson, S. A. in Sabatelli, R. M. (2007). Family interaction: A multigenerational developmental perspective. Boston, MA, ZDA: Pearson Education.

Aucoin, K., Frick, P. J. in Bodin, S. D. (2006). Corporal punishment and child adjustment. Journal of Applied Developmental Psychology, 27(6), 527-541.

Barlow, D. H. in Durand, V. M. (2005). Abnormal psychology. An integrative approach. Belmont, CA, ZDA: Wadsworth.

Baumrind, D., Larzelere, R. E. in Cowan, P. A. (2002). Ordinary physical punishment: Is it harmful? Comment on Gershoff (2002). Psychological Bulletin, 128(4), 580-589.

Brown, T. A., Chorpita, B. F. in Barlow, D. H. (1998). Structural relationships among dimensions of the DSM-IV anxiety and mood disorders and dimensions of negative affect, positive affect, and autonomic arousal. Journal of Abnormal Psychology, 107(2), 179-192.

Caprara, G. V., Regalia, C. in Bandura, A. (2002). Longitudinal impact of perceived self-regulatory efficacy on violent conduct. European Psychologist, 7(1), 63-69.

Caprara, G. V., Scabini, E., Barbaranelli, C., Pastorelli, C., Regalia, C. in Bandura, A. (1998). Impact of adolescents' percieved self-regulatory efficacy on familial communication and antisocial conduct. European Psychologist, 3(2), 125-132.

Carver, C. S. in Scheier, M. F. (2003). Self-regulatory perspectives on personality. $\mathrm{V} \mathrm{T}$. Millon in $\mathrm{M}$. J. Lerner (ur.), Handbook of psychology: Vol. 5. Personality and social psychology ( str. 185-208). Hoboken, NJ, ZDA: Wiley \& Sons.

Chorpita, B. F. in Barlow, D. H. (1998). The development of anxiety: The role of control in the early environment. Psychological Bulletin, 124(1), 3-21.

Futa, K. T., Nash, C. L., Hansen, D. J. in Garbin, C. P. (2003). Adult survivors of childhood abuse: An analysis of coping mechanisms used for stressful childhood memories and current stressors. Journal of Family Violence, 18(4), 227-239.

Gershoff, E. T. (2002). Corporal punishment by parents and associated child behaviors and experiences: A meta-analytic and theoretical review. Psychological Bulletin, 128(4), 539-579.

Gostečnik, C. (2004). Relacijska družinska terapija [Relational family therapy]. Ljubljana, SLO: Brat Frančišek in Frančiskanski družinski inštitut.

Gostečnik, C. (2007). Relacijska zakonska terapija [Relational marital therapy]. Ljubljana: Brat Frančišek in Frančiškanski družinski inštitut.

Gostečnik, C. (2009). Me imata kaj rada [Do you two care about me]. Ljubljana: Brat Frančišek in Frančiškanski družinski inštitut.

Grogan-Kaylor, A. (2004). The effect of corporal punishment on antisocial behavior in children. Social Work Research, 28(3), 153-162.

Harper, F. W. K. in Arias, I. (2004). The role of shame in predicting adult anger and depressive symptoms 
among victims of child psychological maltreatment. Journal of Family Violence, 19(6), 367-375.

Hindy, C. G. in Schwarz, J. C. (1994). Anxious romantic attachment in adult relationships. V M. B. Sperling in W. H. Berman (ur.), Attachment in adults: Clinical and developmental perspective (str. 179-203). New York, NY, ZDA: The Guilford Press.

Kornhauser, P. in Pleterski-Rigler, D. (2007). Zagotovimo našim otrokom mladost brez telesnega kaznovanja [Let us assure the youth without corporal punishment for our children]. V P. Kornhauser (ur.), Zagotovimo našim otrokom mladost brez telesnega kaznovanja [Let us assure the youth without corporal punishment for our children] (str. 54-98). Ljubljana, SLO: Zveza prijateljev mladine Slovenije.

Larzelere, R. E. (2000). Child outcomes of nonabusive and customary physical punishment by parents: An updated literature review. Clinical Child and Family Psychology Review, 3(4), 199-221.

Lynch, S. K., Turkheim, E., D’Onofrio, B. M., Mendle, J., Emery, R. E., Slutske, W. S. in Martin, N. G. (2006). A genetically informed study of the association between harsh punishment and offspring behavioral problems. Journal of Family Psychology, 20(2), 190-198.

Maccoby, E. E. in Martin, J. A. (1983). Socialization in the context of the family: Parent-child interaction. V P. H. Mussen (ur.), Handbook of child psychology: Vol. 4. Socialization, personality, and social developement (str. 1-101). New York, NY, ZDA: John Wiley.

MacMillan, H. L., Boyle, M. H., Wong, M. Y., Duku, E. K., Fleming, J. E. in Walsh, C. A. (1999). Slapping and spanking in childhood and its association with lifetime prevalence of psychiatric disorders in a general population sample. Canadian Medical Association Journal, 161(7), 805-820.

Miller, A. (1979). The drama of the gifted child: The search for the true self. New York: Basic Books.

Mulvaney, M. K. in Mebert, C. J. (2007). Parental corporal punishment predicts behavior problems in early childhood. Journal of Family Psychology, 21(3), 389-397.

Oddone Paolucci, E. in Violato, C. (2004). A meta-analysis of the published research on the affective, cognitive, and behavioral effects of corporal punishment. The Journal of Psychology, 138(3), 197-221.

Olsen, L. R., Jensen, D. V., Noerholm, V., Martiny, K. in Bech, P. (2003). The internal and external validity of the Major Depression Inventory in measuring depressive states. Psychological Medicine, 33(2), 351-356.

Olsen, L. R., Mortensen, E. L. in Bech, P. (2004). The SCL-90 and SCL-90R versions validated by item response models in a Danish community sample. Acta Psychiatrica Scandinavica, 110(3), 225-229.

Peček Čuk, M. in Lesar, I. (2009). Moč vzgoje: Sodobna vprašanja teorije vzgoje [The power of childrearing: Current questions on the theory of childrearing]. Ljubljana: Tehniška založba Slovenije.
Poljak, S. (2009). Discipliniranje otrok v družini - načini, stališča in medgeneracijske povezave [Discplining children in the family: practices, attitudes and crossgenerational connections]. Psihološka obzorja, 18(4), 93-113.

Rothschild, B. (2000). The body remembers: The psychophysiology of trauma and trauma treatment. New York; NY, ZDA: W. W. Norton \& Company.

Salkind, N. J. (2002). Child developement. New York, NY, ZDA: Micmillan Library Reference.

Socolar, R. R. S., Savage, E. in Evans, H. (2007). A longitudinal study of parental discipline of young children. Southern Medical Journal, 100(5), 472-477.

Socolar, R. R. S., Savage, E., Keyes-Elstein, L. in Evans, H. (2005). Factors that affect parental disciplinary practices of children aged 12 to 19 months. Southern Medical Journal, 98(12), 1181-1191.

Straus, M. A. (1994). Beating the devil out of them: Corporal punishment in American families. San Francisco, CA, ZDa: Jossey-Bass/Lexinton Books.

Straus, M. A. (2010a, 22. junij). International parenting study. Pridobljeno 1. spetembra 2010, s spletne strani http://pubpages.unh.edu/ mas2/IPS.htm

Straus, M. A. (2010b, 24. avgust). Preliminary list of nations in the international parenting study. Pridobljeno 1. oktobra 2010, s spletne strani http://pubpages.unh. edu/ mas2/IPS-Nations.htm

Straus, M. A. in Fauchier, A. (2007). Manual for the Dimensions of Discipline Inventory (DDI). Durham, NH, ZDA: Family Research Laboratory.

Straus, M. A. in Field, C. J. (2003). Psychological aggression by American parents: National data on prevalence, chronicity and severity. Journal of Marriage and Family, 65(4), 795-808.

Straus, M. A. in Mouradian, V. E. (1998). Impulsive corporal punishment by mothers and antisocial behavior and impulsiveness of children. Behavioral Sciences and the Law, 16, 353-374.

Straus, M. A. in Stewart, J. H. (1999). Corporal punishment by American parents: National data on prevalence, chronicity, severity, and duration, in relation to child and family characteristics. Clinical Child \& Family Psychology Review, 2(2), 55-70.

Straus, M. A., Sugarman, D. B. in Giles-Sims, J. (1997). Spanking by parents and subsequent antisocial behavior of children. Archives of Pediatrics \& Adolescent Medicine, 151(8), 761-767.

Stuewig, J. in McCloskey, L. A. (2005). The relation of child maltreatment to shame and guilt among adolescents: Psychological routes to depression and delinquency. Child Maltreatment, 10(4), 324-336.

Trumbull, D. A., Larzelere, R. E., Wolraich, M. in Trumbull, D. A. (1999). To spank or not to spank. Pediatrics, 103, 696-698.

Prispelo/Received: 23.2 .2012 Sprejeto/Accepted: 6.5.2013 